\title{
Determinants of Employee Performance: Case Study Pt Cherry Hotel Group Medan
}

\author{
Tine Yuliantini ${ }^{1}$ Deden Kurniawan ${ }^{2}$ Suryono Efendi ${ }^{3}$ \\ Faculty of Economic and Business Universitas Mercu Buana \\ Faculty of Economic and Business Universitas Nasional
}

\section{ABSTRACT}

The purpose of this research analyzes the compensation, work discipline and physical work environment can influence the employee performance in PT Cherry Hotel Group Medan on 2019 The research is using Probability Sampling Simple Random Sampling with the statistical calculation tools produced by the SPSS (Statistical Product Service Solution) 17.0 program and The primary data use with give the form of questionnaires to 102 employees the result shows that the compensation, work discipline, and physical work environment showing a positive and significant impact on employee performance seen from the analysis of comparative linear regression calculation compensation has a regression coefficient of 0.273 , the work discipline has a regression coefficient of 0.304 and the physical work environment has a regression coefficient of 0.403 , it indicates that compensation, work discipline and a good physical work environment will improve the performance of PT Cherry Hotel Group Employee.

Keywords: Compensation, Work Discipline, Physical Work Environment, Performance

DOI: $10.7176 / J R D M / 69-06$

Publication date:September $30^{\text {th }} 2020$

\section{INTRODUCTION}

Business competition continues to increase from time to time as a result of the growth of new competitors from similar products, substitute products, and other products, both coming from within the country and abroad. Human resource management plays a decisive role in the life of an organization, namely how well the organization performs, how well the organization's strategy is carried out, and how far the predetermined goals can be achieved.( Yuliantini 2019). Human resource management is an activity of planning, procuring, developing, maintaining, and using human resources to achieve goals both individually and in an organization (Sutrisno, 2012). In this era, business competition is very tight, companies must be able to continue to compete if they want to continue to survive in business competition (Marlapa 2019). Business competition can be won if the organization can maintain its employees well. Every organization will always try to improve the performance of its employees, with the hope that what the organizational goals will be achieved. That is the importance of employee performance, because employee performance is about doing the job and the results achieved from the job (Wibowo, 2015). Good employee performance is one very important factor in an agency's effort to increase productivity. According to Latb et al (2016) there are many factors to improve employee performance including motivation, organizational culture, company commitment, leadership, job satisfaction, discipline, work environment and compensation ((Soelton, 2019). In terms of performance improvement seen from the compensation factor where Compensation is a reward for everything received by employees as remuneration for contribution to the company or organization (Ardana, 2012) where adequate rewards received by employees will motivate employees to work better. In addition to paying attention to compensation, one of the coaching efforts carried out in order to improve employee work performance is to increase employee work discipline. Discipline is very important in organizational growth, discipline is used as a tool to motivate employees to carry out their work individually or in groups (Yuliantini, 2019). With the higher work discipline of each employee who is supported by skills, wages, or a decent salary, it will affect the activities of the employees themselves (Hasibuan, 2013).

Companies also need to pay attention to the work environment to improve employee performance. The work environment is a very important component in employees carrying out work activities. The definition of the work environment here is everything that is around the workers and which can affect them in carrying out their assigned tasks (Sunyoto, 2012).

PT Cherry Hotel Group, is a company located in the city of Medan which is engaged in accommodation services which was founded in 2000. PT Cherry Hotel Group is required to show good performance of its employees in carrying out their main duties and functions and to optimize the effectiveness and efficiency of employees. Accommodation service companies certainly have to prioritize optimal service for their customers. The success of its employees in their main duties as service providers that guests expect must be the main achievement goal of the company because the success achieved by PT Cherry Hotel Group in carrying out its main duties and functions is of course strongly influenced by the success of its employees. The success or failure of an employee at work will be known if the organization in question implements an employee performance appraisal system.

Routine work appraisals are carried out by PT Cherry Hotel Group once a month in a year, employee appraisals are carried out directly by the leaders who are responsible for employee appraisals and are carried out in all parts under the auspices of PT Cherry Hotel Group, as a company engaged in the accommodation service industry among others, the hotel department, the marketing department, the human resources department, and the finance department. The main parts in carrying out the company's activities, the writer gets some data which shows that the performance of PT Cherry Hotel Group employees is still not optimal, one of which is the average value in the recapitulation data of the performance value of employees at PT Cherry Hotel Group which indicates that performance is still not optimal. employees. 
The results of the author's survey show a phenomenon of the report recapitulation of the average percentage of the employee performance value of PT Cherry Hotel Group from 2015 - 2019:

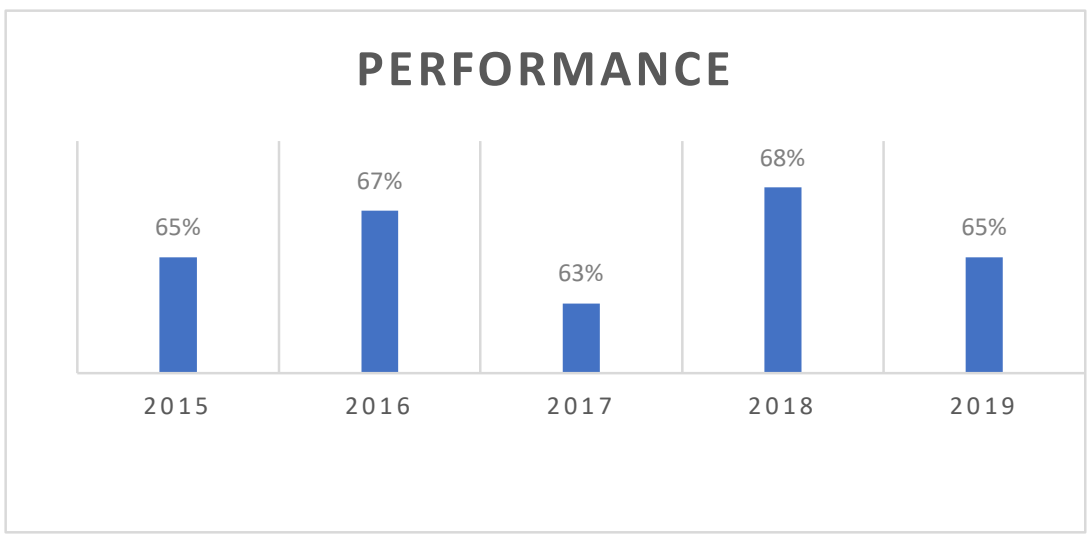

Figure 1.1 Percentage Report Diagram

Average Performance Value of PT Cherry Hotel Group Employees

From Figure 1.1 it can be seen that the report on the average percentage of employee performance values tends to fluctuate, this is according to information sourced from the main leadership, it can be said that the performance at PT Cherry Hotel Group is not optimal. In addition, employees have not shown good performance through work discipline as seen from the percentage reports of tardiness and absenteeism of employees.

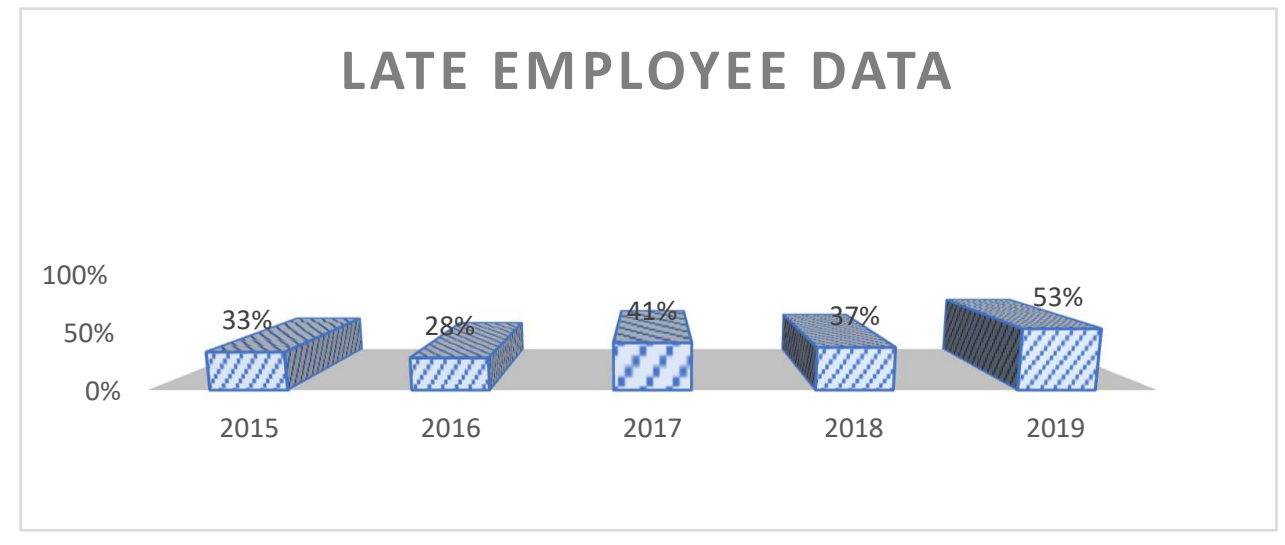

Figure 1.2 Percentage Report Diagram

Delays in Employees of PT Cherry Hotel Group 2019

In Figure 1.2, it can be seen that the report on the percentage of tardiness and absenteeism or employee absenteeism per year tends to fluctuate and has not been said to be optimal. It is estimated that there are still some employees who have not been able to come according to the time set by the company.

In addition to the data that has been previously described, to strengthen the researchers' suspicions about sub-optimal performance, the researchers conducted pre-research interviews. According to the results of the pre-research interview conducted on February 10, 2020 to the leadership of the HR division of PT Cherry Hotel Group, it turns out that there are some employees who have not optimal performance because there are still employees who have not completed work on time, lack of initiative in work, lack of office facilities. sufficient so that work is hampered. Employees receive low salaries for their work. Based on the results of interviews, employees demand to be given more salaries, because according to them their life is always increasing every year. This study is to determine the effect of compensation, work discipline and work environment on the performance of employees of PT Cherry Hotel Group Medan in 2019 where information about employee performance in an organization is an important thing to use to evaluate whether the performance processes carried out by the organization have 
been running with the same objectives. expected or not. Based on the explanation above, the objectives and uses of this study are:

1. To determine the effect of compensation on the performance of employees of PT Cherry Hotel Group Medan in 2019.

2. To analyze and determine the effect of work discipline on the performance of employees of PT Cherry Hotel Group Medan in 2019 ..

3. To analyze and determine the effect of the physical work environment on the performance of employees of PT Cherry Hotel Group Medan in 2019.

This research provides suggestions or input to take the right steps in order to improve the quality of compensation, work discipline, and the physical work environment on employee performance, especially employees at PT Cherr4y Hotel Group.

\section{THEORY AND HYPOTHESIS}

\section{Human Resources}

According to Kaswan (2012) Human Resource Management (MSDM) is part of management which includes planning, organizing, directing, and monitoring. HRM handles human resources, namely people who are ready, willing and able to contribute to stakeholder goals. HRM pays attention to human welfare in the organization so that they can work together effectively and contribute to organizational success. HRM is a system that has several functions, policies, activities, or practices including recruitment, selection, development, compensation, retention, evaluation, promotion, and others.

\section{Employee performance}

Wilson (2012), explains that improving employee performance is what employers and workers want. Employers want their employees' performance to be good for the benefit of increasing work results and company profits. On the other hand, workers have an interest in self-development and job promotion. In general, it can be said that good employee performance aims to increase productivity. Therefore, repair work systems are carried out by each component in the company. For this purpose a good performance management system will be required.

According to Wilson (2012), performance is the result of work achieved by a person based on job requirements (job requirements). A job has certain requirements to be able to achieve goals which are also known as job standards. Performance is about what is done and how to do it (Wibowo, 2015).

Factors that affect performance in this study:

a. Compensation

b. Work discipline

c. Physical work environment

Performance appraisal serves several purposes. Hanggraeni (2012), the objectives of performance appraisal are as follows:

1) Making decisions in HR management such as promotions, transfers and dismissals

2) Identifying needs for training and development

3) Validating the selection and development program

4) Provide feedback to workers on their performance

5) The basis for determining remuneration allocation decisions

\section{Compensation}

The definition of compensation according to Gary Dessler is any form of payment or compensation that is given to an employee and arises from the employee's employment (Gary Dessler 1997)

Compensation is everything that employees receive in return for their work (Sedarmayanti, 2013). Compensation or compensation is something that is received by employees as remuneration provided by the organization for the work that has been done (Hanggrae 2010)

Compensation consists of two general forms, namely direct compensation (consisting of (a) salary and basic wages, and (b) incentives and profit sharing) and indirect compensation (in the form of welfare and service programs). Indirect compensation 
can be classified into two types (a) provided voluntarily by employers, and (b) required by law / regulation (Marwansyah, 2012)

Hasibuan (2013) explains that compensation can be divided into two, namely direct compensation in the form of salaries, wages and incentive wages. Indirect compensation (indirect compensation or employee welfare).

a) Direct Compensation

(1) Salary

Salary is money paid to employees for services provided on a monthly basis (Mangkunegara, 2011: 85). Salary is a remuneration that is paid periodically to permanent employees and has a definite guarantee. That is, the salary will still be paid even if the worker does not come to work (Hasibuan, 2013).

(2) Incentives

Hasibuan (2013) argues that incentives are incentives given to certain employees based on their work performance so that employees are encouraged to increase their work productivity. Incentives as a form of company compensation to employees are based on the performance they show. The better the performance displayed by the worker, the more incentives they will receive (Hanggraeni, 2012).

b) Indirect Compensation

According to Marwansyah (2012) indirect compensation forms are:

(1) What is required by law / regulation

(a) Social security, such as Jamsostek which includes work accident benefits, old age benefits, and death benefits.

(b) Remuneration when not working, for example severance pay or salary when the employee is laid off.

(c) Compensation for workers, for example health insurance programs and occupational accident insurance.

(2) Given voluntarily

Payment for non-work (payment for time not work), including time off, annual leave, sick leave, leave for essential purposes, and holidays.

(a) Employee welfare, including medical and health care costs.

(b) Employee services, including cooperatives, places of worship, sports and recreation programs, parking areas, discounts for company products, scholarships for education and so on.

(c) Premium (premium pay), which includes additional money for employees whose jobs are high risk and employees who work on night shifts.

The objectives of the compensation system according to Sedarmayanti (2013) are:

a) Rewarding performance

b) Guarantee justice

c) Retaining employees

d) Obtain quality employees

e) Controlling costs

f) Compliance with regulations

Compensation System

According to Ardana (2012), the compensation payment system includes:

1. Time system

Compensation (salary, wages) is determined based on time standards such as: hours, days, weeks or months.The wage administration is relatively easy to apply to both permanent employees and daily workers. This system is applied if the work performance is difficult to measure per unit and for permanent employees the compensation is paid over the time system on a monthly basis. The amount of compensation is only based on the length of work, not related to work performance

\section{Results System (output)}


a) Compensation or wages determined for units produced by workers. Such as intersections, meters, liters, kilo grams.

b) Compensation paid is always based on the number of results done, not on the length of time to do it

c) Cannot be assigned to permanent employees, and types of work that do not have physical standards such as administrative employees

\section{Wholesale system}

a) A method of remuneration in which the placement / determination of the amount of services is based on the volume of work and the time spent doing it.

b) Determining the amount of remuneration based on this system is quite complicated, it takes time to work on it and how many tools are needed to complete it.

c) In a wholesale system requires precise calculations to obtain reasonable remuneration, correct calculations.

\section{Work Discipline}

According to Rivai \& Sagala (2013) work discipline is a tool used by managers to communicate with employees so that they are willing to change a behavior and to increase awareness as well as a person's willingness to obey all the rules and social norms that apply in a company.

According to Handoko (2012) there are two forms of work discipline, namely preventive discipline and corrective discipline:

1. Preventive discipline, is an effort to move employees to follow and comply with work guidelines, the rules outlined by the company. Its basic purpose is to mobilize self-disciplined employees. With a preventive way, employees can maintain themselves against company or agency regulations.

2. Corrective discipline is an effort to mobilize employees to unite a ruleand directs to comply with the regulations in accordance with the guidelines that apply tocompany or organization.

\section{Physical Work environment}

Work environment is the entire work facilities and infrastructure that are around employees who are doing work that can affect the implementation of work (Sutrisno, 2012).

Types of work environment

Sedarmayanti (2013) states that broadly speaking, the types of work environments are divided into 2 (two).

1. Physical work environment (physical working environment).

Sedarmayanti (2013) states that: "The physical work environment is all situations physical form that is located around the workplace which can affect both employees directly or indirectly. "

2. non-physical working environment

Sedarmayanti (2013) states that: "Non-physical work environments are all situations what happens is related to work relationships, both relationships with superiors and relationships fellow co-workers, or relationships with subordinates. "

The Factors that affect the physical work environment (Sedarmayanti, 2013) are:

1. Lighting / lighting at work

2. Temperature at work

3. Humidity at work

4. Air circulation in the workplace

5. Noise at work

6. Mechanical vibrations at work

7. Smells at work

8. Color arrangement at work

9. Decoration at work

10. Music at work

11. Security at work 
Operational Variable

\begin{tabular}{|c|l|l|}
\hline $\begin{array}{c}\text { Variable } \\
\text { (Y) }\end{array}$ & \multicolumn{1}{|c|}{ Definition } & \multicolumn{1}{c|}{ Indicator } \\
\hline $\begin{array}{c}\text { Employee performnce } \\
\text { of people in an organization in accordance with their respective } \\
\text { authorities and responsibilities. }\end{array}$ & $\begin{array}{l}\text { Performance is a work result } \\
\text { work } \\
- \text { Accuracy of work } \\
\text { results } \\
\text {-Cooperate }\end{array}$ \\
\hline $\begin{array}{c}\text { compentation } \\
\left(\mathrm{X}_{1}\right)\end{array}$ & $\begin{array}{l}\text { All income in the form of money, direct or indirect goods received by } \\
\text { employees in return for services provided to the company. }\end{array}$ & $\begin{array}{l}\text { - Salary } \\
\text { - Wages } \\
\text { - Insurance }\end{array}$ \\
\hline $\begin{array}{c}\text { Work displine } \\
\left(\mathrm{X}_{2}\right)\end{array}$ & $\begin{array}{l}\text { Good employee work discipline if absences are not more than three } \\
\text { times a month and follow the rules and ethical norms given. }\end{array}$ & $\begin{array}{l}\text { - Obey the rules of time } \\
\text { - Compliance with } \\
\text { company regulations } \\
\text { - Obeying the rules of } \\
\text { conduct at work }\end{array}$ \\
\hline $\begin{array}{c}\text { Physical Working } \\
\text { enviroment }\end{array}$ & $\begin{array}{l}\text { The physical work environment is everything that is in the } \\
\text { environment of the workers that can affect him in carrying out his job. }\end{array}$ & $\begin{array}{l}\text { - Lighting at work } \\
\text { - Air circulation in the } \\
\text { workplace } \\
\text { - Decoration at work }\end{array}$ \\
\hline
\end{tabular}

\section{Frame work}

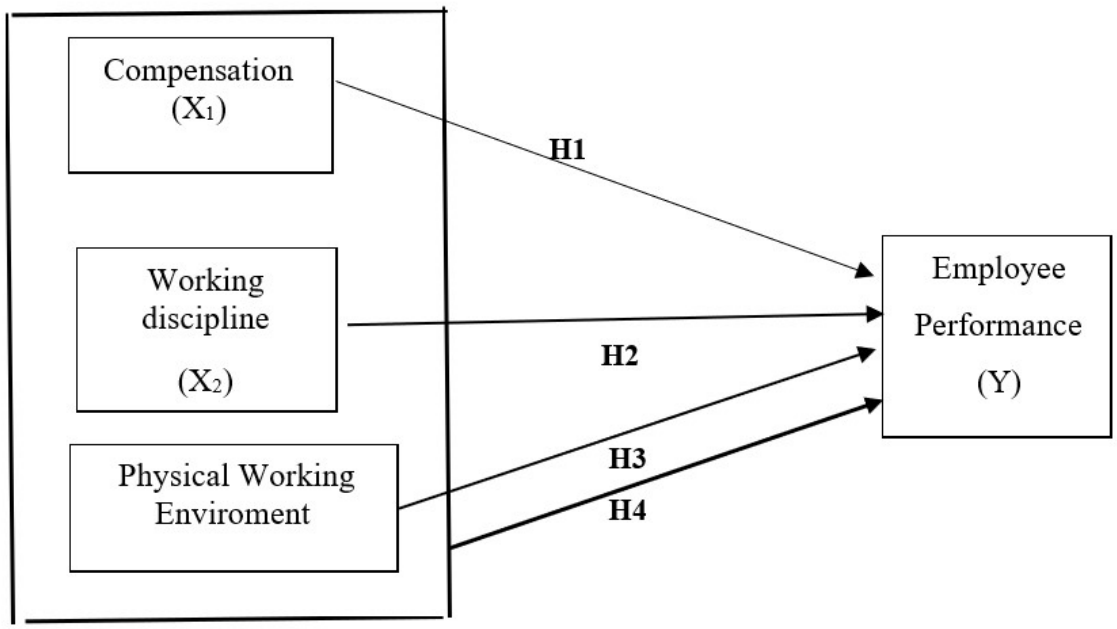

\section{RESEARCH METHOD}

This research method uses a quantitative approach with survey techniques. This research is an individual study examining employee performance which is influenced by compensation, work discipline, and physical work environment. The object of research in this study were employees of PT Cherry Hotel Group Medan in 2019.

\section{Population and Sample}

\section{Population}

Population is an area consisting of objects / subjects that have certain qualities and characteristics that are determined by researchers to study and then draw conclusions (Sugiyono, 2012: 215). The population in this study were employees of PT Cherry Hotel Group with 137 employees.

\section{Sample}

According to Sugiyono (2010) the sample is part of the number or characteristics possessed by the population. Samples taken as respondents are employees with the Probability Sampling technique (simple random sampling) which provides equal opportunities for each member of the population to be selected as a member of the sample. The Slovin formula is used to determine the sample size of a known population, which is 137 employees, and 102 as a sample 


\section{RESEARCH RESULTS AND DISCUSSION}

\section{Characteristics of Respondent}

Based on gender from 102 respondents, the percentage of male respondents was $72 \%$ or as many as 73 people, while female respondents were $28 \%$ or 29 people. When viewed by age, the percentage of respondents aged $20-30$ years was $20 \%$ or as many as 20 people, $47 \%$ or as many as 48 people aged $31-50$ years, aged $>50$ years was $33 \%$ or as many as 34 people. Based on the latest education, it can be seen that the percentage of respondents with the latest high school / equivalent education background is $9 \%$ or as many as 9 people, respondents with a D3 education background are $34 \%$ or as many as 35 people, respondents with an undergraduate education background are $43 \%$ or as much 44 people, respondents with S2 background were $14 \%$ or as many as 14 people. Based on the working period, it can be seen that the percentage of respondents who work between $0-5$ years is $21 \%$ or as many as 21 people, respondents who work between $6-10$ years are $34 \%$ or as many as 35 people, respondents who work between $11-15$ years are $27 \%$ or as many as 28 people, respondents who worked $>15$ years of $18 \%$ or as many as 18 people.

Validity and Reliability Test

Based on validity and reliability testing that has been carried out by 30 respondents, all statement items are declared valid and reliable.

Description of Data

Total Mean Compensation

\begin{tabular}{|c|c|c|}
\hline \multicolumn{3}{|c|}{ Salary } \\
\hline 1. & On time & 4,51 \\
\hline 2. & Achieve UMR & 4,43 \\
\hline \multicolumn{2}{|r|}{ Total Mean } & 4,47 \\
\hline \multicolumn{3}{|c|}{ Incentive } \\
\hline 3. & Improve my spirit & 4,25 \\
\hline 4. & According work year & 4,45 \\
\hline \multicolumn{2}{|r|}{ Total Mean } & 4,35 \\
\hline \multicolumn{3}{|c|}{ Insurance } \\
\hline 5. & Direct BPJS & 4,43 \\
\hline 6. & Feel safe & 4,36 \\
\hline \multicolumn{2}{|r|}{ Total Mean } & 4,395 \\
\hline \multicolumn{2}{|r|}{ Total Mean compensation } & 4,405 \\
\hline
\end{tabular}

Total Mean

Discipline 


\begin{tabular}{|c|l|l|}
\hline \multicolumn{2}{|c|}{ Obey on working time } & 4,15 \\
\hline 1. & Working on time required & 4,30 \\
\hline 2. & Come earlier Obey working rule & 4,225 \\
\hline \multicolumn{2}{|c|}{ Total Mean } & 4,16 \\
\hline \multicolumn{2}{|c|}{ Total Mean } & 4,15 \\
\hline 3. & Recently come and go on time company rule & 4,155 \\
\hline 4. & Attention of working procedure & 4,36 \\
\hline \multicolumn{2}{|c|}{ Obey } & 4,39 \\
\hline 5. & Rarely to inform permit letter if not & 4,375 \\
\hline 6. & Leave on working time & 4,252 \\
\hline \multicolumn{2}{|c|}{ Total Mean Mean discipline } & \\
\hline & Total & \\
\hline
\end{tabular}

Total Mean

Working environment

\begin{tabular}{|l|l|l|}
\hline \multicolumn{2}{|l|}{ Air circulation } & 4,07 \\
\hline 1. & Bad air circulation & 4,44 \\
\hline 2. & Temperature not ideal & 4,255 \\
\hline Total Mean & \multicolumn{2}{l|}{} \\
\hline Lighting & Good lighting & 4,44 \\
\hline 3. & Low lighting & 4,07 \\
\hline 4. & 4,255 \\
\hline Total Mean & \multicolumn{2}{|l|}{} \\
\hline Decoration & Layout not good & 4,44 \\
\hline 5. & Lack space movement. & 4,44 \\
\hline 6. & 4,44 \\
\hline Total Mean & 4,316 \\
\hline Total Mean working environmental & \\
\hline
\end{tabular}


Total Mean

Employee performance

\begin{tabular}{|l|l|l|}
\hline \multicolumn{2}{|l|}{ Precise } & 4,18 \\
\hline 1. & On time & 4,36 \\
\hline 2. & Time forecast & 4,27 \\
\hline Total Mean & 4,39 \\
\hline Job result & \multicolumn{2}{l|}{} \\
\hline 3. & On time & 4,35 \\
\hline 4. & On target & 4,37 \\
\hline Total Mean & 4,44 \\
\hline Team building & 4,49 \\
\hline 5. & Good respect on relation and helping others & 4,465 \\
\hline 6. & Time work & 4,368 \\
\hline \multicolumn{2}{|l|}{ Total Mean } & \\
\hline Total Mean employee performance & \\
\hline
\end{tabular}

Source : process in 2019

Based on the results of descriptive statistical analysis, seen from the total mean of each variable.

Compensation (X1) reached a mean value of 4.405 , which means that most respondents agreed that the compensation provided was good enough. Work discipline (X2) reaches a mean value of 4.252, which means that most respondents agree that the work discipline applied is not good. The physical work environment (X3) reaches a mean value of 4,316, which means that most respondents agree that the physical work environment provided is not good. Performance (Y) reaches a mean value of 4.368, which means that most respondents agree that the employee's performance is good.

Based on the results of the Kolmogorov - Smirnov Test above, the unstandardized residual of the Kolmogorov Asymp.Sig (2tailed) is 0.680 which means that it is greater than 0.05 , indicating that the data on the research variables are normally distributed.

\section{Multicollinearity Test}

The multicolinearity test can be seen from the Variance Inflation Factor (VIF) and Tolerance values, if the VIF value is less than 10 and the Tolerance is more than 0.1 it is declared that there is no multicolinearity. A good regression model does not have perfect or near perfect correlation among the independent variables (multicollinearity).

Coefficients
\begin{tabular}{|l|r|r|}
\hline \multirow{2}{*}{ Model } & \multicolumn{2}{|c|}{ Collinearity Statistics } \\
\cline { 2 - 3 } & Tolerance & \multicolumn{1}{c|}{ VIF } \\
\hline 1 (Constant) & .231 & \\
K & .284 & 4.326 \\
DK & .190 & 3.518 \\
LKF & & 5.257 \\
\hline
\end{tabular}

Dependent Variable: Performance

$\mathrm{K}=$ compentation, $\mathrm{DK}=$ Dicipline, $\mathrm{LKF}=$ working environment 


\section{Hypothesis test}

The $t$ test (partial regression test) is used to determine whether partially each independent variable, meaning compensation, work discipline, and physical work environment have a positive effect on employee performance. Based on the results of the $t$ test in Table 4.15, the compensation variable has a significant relationship to the employee performance of PT Cherry Hotel Group Medan. This can be seen from the $t$ value of 3.409 with a significance level above 0.05 , which is equal to 0.001 . The increase in compensation significantly affects the increase in employee performance. This shows that compensation has the ability to improve employee performance.

The results of the next $t$ test, namely the work discipline variable, obtained the $t$ value of 4.214 with a significance level above 0.05 , which is equal to 0.000 . These results indicate that the work discipline variable has a positive and significant effect on the employee performance of PT Cherry Hotel Group Medan, meaning that the higher the work discipline applied, the higher the employee performance of PT Cherry Hotel Group Medan. Physical work environment variables have a positive and significant effect on employee performance at PT Cherry Hotel Group Medan. This is evidenced by the $t$ value obtained at 4.565 with a significance level above 0.05 , which is equal to 0.000 . The findings show that a good physical work environment will trigger an increase in the performance of employees of PT Cherry Hotel Group Medan.

The results above indicate that the three VIF values of the variables are $<10$ and the Tolerance value is more than 0.1 , which means that the regression model does not contain multicollinearity.

\section{Heteroscedasticity Test}

The heteroscedasticity test using the glacier test aims to test whether in the regression model there is an inequality of variance from the residuals of one observation to another. A good regression model does not occur heteroscedasticity.

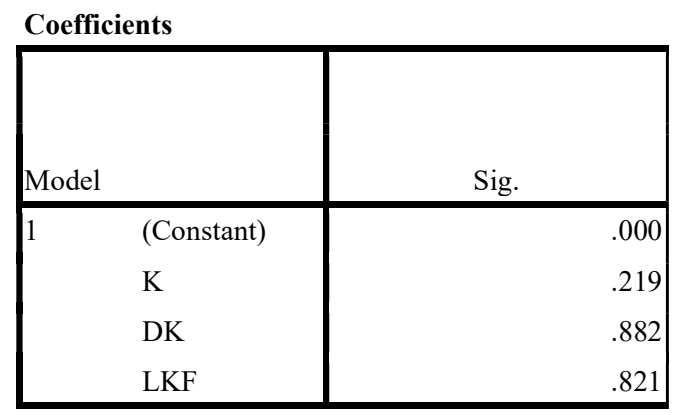

Dependent Variable: Performance

$\mathrm{K}=$ compentation, $\mathrm{DK}=$ Dicipline, $\mathrm{LKF}=$ working environment

Source: Processed Data SPSS 17.0

Based on the heteroscedasticity test with the glacier method, the significance value is greater than 0.05 , so it can be said that the data does not occur heteroscedasticity problems.

Autocorrelation Test

\begin{tabular}{|l|r|}
\hline Model & Durbin-Watson \\
\hline 1 & 1.994 \\
\hline
\end{tabular}

The autocorrelation test is used to determine the relationship between existing data on the research variables. A good regression model should not have autocorrelation. The test method uses the Durbin-Watson test (DW Test). To detect the presence or absence of autocorrelation, if the value of DW is between $\mathrm{dU}$ and 4-dU, then there is no autocorrelation.

Double regression 


\begin{tabular}{|c|c|c|c|c|c|c|}
\hline \multicolumn{7}{|c|}{ Coefficients } \\
\hline \multirow{2}{*}{\multicolumn{2}{|c|}{ Model }} & \multicolumn{2}{|c|}{$\begin{array}{c}\text { Unstandardized } \\
\text { Coefficients }\end{array}$} & $\begin{array}{l}\text { Standardized } \\
\text { Coefficients }\end{array}$ & \multirow[b]{2}{*}{$\mathrm{T}$} & \multirow[b]{2}{*}{ Sig. } \\
\hline & & B & Std. Error & Beta & & \\
\hline \multirow[t]{4}{*}{1} & (Constant) & 2.043 & 1.019 & & 2.005 & .048 \\
\hline & K & .263 & .077 & .273 & 3.409 & .001 \\
\hline & DK & .288 & .068 & .304 & 4.214 & .000 \\
\hline & LKF & .381 & .083 & .403 & 4.565 & .000 \\
\hline
\end{tabular}

Dependent Variable: Performance

$\mathrm{K}=$ compentation, $\mathrm{DK}=$ Dicipline, $\mathrm{LKF}=$ working environment

Source: Processed Data by SPSS 17.0

1. Compensation has a regression coefficient of 0.273 , if the compensation variable increases by $1 \%$, the employee's performance will also increase by 0.273 where the other variables are fixed. This means that the compensation variable has a positive effect on employee performance. Assuming that the other variables are fixed.

2. Work discipline has a regression coefficient of 0.304 , if the work discipline variable increases by $1 \%$, the employee's performance will also increase by 0.304 where the other variables are fixed. This means that the work discipline variable has a positive effect on employee performance. Assuming that other variables are fixed.

3. The physical work environment has a regression coefficient of 0.403 . If the physical work environment variable increases by $1 \%$, the employee's performance will also increase by 0.403 where the other variables are fixed. This means that physical work environment variables have a positive effect on employee performance. Assuming that other variables are fixed.

\section{Normality test}

The normality test is used to determine whether the data population is normally distributed or not. The data normality test can be done with the Kolmogorov - Smirnov test. The application of the Kolmogorov - Smirnov test is that if it is significant below 0.05 , it means that the data to be tested has a significant difference with standard normal data, it means that the data is not normal. Based on the results of descriptive statistical analysis, seen from the total mean of each variable. Compensation (X1) reached a mean value of 4.405 , which means that most respondents agreed that the compensation provided was good enough. Work discipline (X2) reached a mean value of 4.252, which means that most respondents agreed that the work discipline applied was not good. The physical work environment (X3) reaches a mean value of 4,316, which means that most respondents agree that the physical work environment provided is not good. Performance (Y) reaches a mean value of 4.368, which means that most respondents agree that the employee's performance is good.

Table 4.11

Result Normalitas Test

One-Sample Kolmogorov-Smirnov Test

\begin{tabular}{|c|c|c|}
\hline & Unstandardized Residual \\
\hline $\mathrm{N}$ & & 102 \\
\hline Normal & Mean & .0000000 \\
\hline al anters & Std. Deviation & .94128755 \\
\hline Most Extreme & Absolute & .071 \\
\hline Dinterentives & Positive & .071 \\
\hline & Negative & -.064 \\
\hline Kolmogorov-S & nirnov Z & .719 \\
\hline Asymp. Sig. (2 & tailed) & .680 \\
\hline
\end{tabular}

a. Test distribution is Normal.

b. Calculated from data. 
based on the results of the Kolmogorov - Smirnov Test above, the unstandardized residual of the Kolmogorov Asymp.Sig (2-tailed) is 0.680 which means that it is greater than 0.05 , indicating that the data on the research variables are normally distributed.

\section{Multicollinearity Test}

The multicolinearity test can be seen from the Variance Inflation Factor (VIF) and Tolerance values, if the VIF value is less than 10 and the Tolerance is more than 0.1 it is declared that there is no multicolinearity. A good regression model does not have perfect or near perfect correlation among the independent variables (multicollinearity).

Resource: Data processed by SPSS 17.0

Tabel 4.12

Hasil Uji Multikolineritas

Coefficients ${ }^{\mathrm{a}}$

\begin{tabular}{|l|r|r|}
\hline \multirow{2}{*}{ Model } & \multicolumn{2}{|c|}{ Collinearity Statistics } \\
\cline { 2 - 3 } & Tolerance & \multicolumn{1}{c|}{ VIF } \\
\hline 1 (Constant) & .231 & \\
K & .284 & 4.326 \\
DK & .190 & 3.518 \\
LKF & 5.257 \\
\hline
\end{tabular}

Dependent Variable: Kinerja

$\mathrm{K}=$ Kompensasi, $\mathrm{DK}=$ Disiplin Kerja, $\mathrm{LKF}=$ Lingkungan Kerja Fisik

Resource : Data processed by SPSS 17.0

\section{F test}

The $\mathrm{F}$ test is used to test the significance of the regression coefficient together, namely whether the independent variable has an influence on the dependent variable that is tested at a significant level of 0.05 . In this case the ANOVA table is used to test the significant effect of compensation, work discipline, and the physical work environment together on employee performance.

\begin{tabular}{|rl|r|r|r|r|r|}
\hline \multicolumn{7}{|c|}{ ANOVA $^{\mathbf{b}}$} \\
Model & & $\begin{array}{c}\text { Sum of } \\
\text { Squares }\end{array}$ & $\mathrm{df}$ & $\begin{array}{c}\text { Mean } \\
\text { Square }\end{array}$ & \multicolumn{1}{c|}{$\mathrm{F}$} & Sig. \\
\hline 1 & $\begin{array}{l}\text { Regressio } \\
\mathrm{n}\end{array}$ & 527.767 & 3 & 175.922 & 192.655 & $.000^{\mathrm{a}}$ \\
& Residual & 89.488 & 98 & .913 & & \\
& Total & 617.255 & 101 & & & \\
\hline
\end{tabular}

a. Predictors: (Constant), LKF, DK, K

dependent Variable: Kinerja

c.K $=$ Kompensasi, DK = Disiplin Kerja, LKF $=$ Lingkungan Kerja Fisik

B.Dependent Variable: Performance

c. $\mathrm{K}=$ Compensation, $\mathrm{DK}=$ Work Discipline, $\mathrm{LKF}=$ Physical Work Environment

From Table 4.16 it can be explained that the $F$ value shows a significance value of $0.000<0.05$. This means that compensation, work discipline, and physical work environment have a positive and significant effect on employee performance at PT Cherry Hotel Group Medan.

\section{Determination Coefficient Test (R2)}

Determination analysis aims to measure how far the model's ability to explain variations in the dependent variable can inform whether the estimated regression model is good or not. 
Table 4.13

Coefficient Determination

\begin{tabular}{|l|r|r|r|}
\hline Model & \multicolumn{1}{|c|}{ Model Summary } \\
\hline 1 & $.925^{\mathrm{a}}$ & \multicolumn{1}{c|}{ R Square } & $\begin{array}{c}\text { Adjusted R } \\
\text { Square }\end{array}$ \\
\hline
\end{tabular}

a. Predictors: (Constant), LKF, DK, K

b. Dependent Variable: Kinerja

Sources : Processed Data by SPSS 17

Based on Table 4.13, the coefficient of determination (R2) is 0.855 , which means that the level of employee performance variables can be influenced by compensation, work discipline, and physical work environment by $85.5 \%$, while the remaining $14.5 \%$ is influenced by other factors not discussed in the study. This.

\section{Hypothesis test}

The $t$ test (partial regression test) is used to determine whether partially each independent variable, meaning compensation, work discipline, and physical work environment have a positive effect on employee performance.

Based on the results of the $t$ test in Table 4.15, the compensation variable has a significant relationship to the employee performance of PT Cherry Hotel Group Medan. This can be seen from the t value of 3.409 with a significance level above 0.05 , which is equal to 0.001 . The increase in compensation significantly affects the increase in employee performance. This shows that compensation has the ability to improve employee performance.

The results of the next $t$ test, namely the work discipline variable, obtained the $t$ value of 4.214 with a significance level above 0.05 , which is equal to 0.000 . These results indicate that the work discipline variable has a positive and significant effect on the employee performance of PT Cherry Hotel Group Medan, meaning that the higher the work discipline applied, the higher the employee performance of PT Cherry Hotel Group Medan.

Physical work environment variables have a positive and significant effect on employee performance at PT Cherry Hotel Group Medan. This is evidenced by the $t$ value obtained at 4.565 with a significance level above 0.05 , which is equal to 0.000 . The findings show that a good physical work environment will trigger an increase in the performance of employees of PT Cherry Hotel Group Medan.

\section{LIMITATION OF RESEARCH}

Due to the limited time of this study, the researcher is only limited to examining the variables that the researcher has chosen to research, namely compensation, work discipline and the physical environment, not adding other variables such as the role of leadership and employee competence which are also very necessary for skills in the field of accommodation services to support performance.

\section{CONCLUSION}

Based on the results of research on compensation, work discipline and physical work environment on employee performance, the following conclusions are obtained:

1. Compensation has a positive and significant effect on employee performance at PT Cherry Hotel Group Medan in 2019. This shows that the greater the compensation received by employees, the greater the employee's performance will be.

2. Work discipline has a positive and significant impact on employee performance at PT Cherry Hotel Group Medanin 2019. This shows that the more work discipline increases, the employee's performance will increase better than before.

3. Physical work environment has a positive and significant influence on employee performance at PT Cherry Hotel Group Medanin 2019 . This shows that the better the physical work environment at PT Cherry Hotel Group, the better employee performance will be.

4. Compensation, work discipline and physical work environment simultaneously have a positive and significant influence on employee performance at PT Cherry Hotel Group Medanin 2019 


\section{IMPLICATIONS}

a. For PT Cherry Hotel Group, PT Cherry Hotel Group should improve the compensation system because can effort to improve employee performance, so the good salary that PT Cherry Hotel Group employees receive can give encouregement their performance better than before. Because the research results prove that compensation can affect employee performance.

b. PT Cherry Hotel Group should more monitoring their g employee attendance so that employees who are absent and late come at work can be reduce and be more disciplined. PT Cherry Hotel Group must also monitor whether the work done by employees is completed on time.

c. PT Cherry Hotel Group should consider improving the existing physical work environment in the company. Employee performance will increase if they feel comfortable with the circumstances around them. If they feel comfortable, the work will be done well and the employee's performance will improve.

d. For further researchers, it is necessary to add other variables that may affect employee performance so that the results can be generalized. For example: the leadership style in PT Cherry Hotel Group.

\section{References}

Ardana, I. K, N W. Mutiaji, dan I W M. Utama. 2012. Manajemen Sumber Daya Manusia. Edisi Pertama. Graha Ilmu. Yogyakarta.

Dessler, Gary. 1997. Management Sumber Daya Manusia. Terjemahan. BenyaminMolan. Edisi Bahasa Indonesia. PT Prenhallind. Jakarta.

Eri Marlapa , Effect of Work Discipline and Work Motivation on Employee Productivity of PT. DensoIndonesia Plan 2 Cibitung Bekasi West Java Journal of Resources Development and Management www.iiste.org ISSN 2422-8397 An International Peer-reviewed Journal Vol.60, 2019

Handoko, T. H. 2012. Manajemen Personalia dan Sumber Daya Manusia. Edisi 2. BPFE. Yogyakarta.

Hanggraeni, D. 2012. Manjemen Sumber Daya Manusia. Cetakan I. Lembaga Penerbit Fakultas Ekonomi Universitas Indonesia. Medan.

Hasibuan, M. S. P. 2013. Manjemen Sumber Daya Manusia. Cetakan Ketujuh. PT. Bumi Aksara. Medan.

Kaswan. 2012. Manajemen Sumber Daya Manusia untuk Keunggulan Bersaing Organisasi. Graha Ilmu. Yogyakarta.

Mangkunegara, A.A. P. 2011. Manajemen Sumber Daya Manusia Perusahaan. PT Remaja Rosdakarya. Bandung.

Marwansyah. 2012. Manajemen Sumber Daya Manusia. Edisi Kedua. Alfabeta. Bandung.

Pebriana Putri 2019. Bagaimana Komflik Peran dan Beban Kerja Mempengaruhi Kinerja Karyawan dengan Burnout Sebagai Variabel Intervening Jurnal Ilmiah Manajemen dan Bisnis, Fakultas ekononi dan Bisnis Universitas Mercu buana

Rivai, V. dan Ella S. 2013. Manajemen Sumber Daya Manusia untuk Perusahaan. Edisi Ketiga. Rajawali Pers, Medan.

Soelton Mochamad 2019. Bagaimana Komflik Peran Dan Beban Kerja Mempengaruhi Kinerja Karyawan dengan Burnout Sebagai Variabel Intervening Jurnal Ilmiah Manajemen dan Bisnis, Fakultas ekononi dan Bisnis Universitas Mercu buana VOL. 5

Sedarmayanti. 2013. Manajemen Sumber Daya Manusia Reformasi Birokrasi dan Manajemen Pegawai Negeri Sipil. PT. Refika Aditama. Bandung.

2011. Manajemen Sumber Daya Manusia Reformasi Birokrasi dan Manajemen Pegawai Negeri Sipil. Cetakan Kelima. PT. Refika Aditama. Bandung.

Sinambela, L. P. 2012. Kinerja Pegawai; Teori Pengukuran dan Implikasi. Graha Ilmu. Yogyakarta.Sugiyono. 2010. Metode Penelitian Kuantitatif Kualitatif dan RND. Alfabeta. Bandung.

2012. Memahami Penelitian Kualitatif. Alfabeta. Bandung.

Sunyoto, D. 2012. Manajemen Sumber Daya Manusia. CAPS (Center Of Academic Publishing Service).Yogyakarta.

Sutrisno, E. 2012. Manajemen Sumber Daya Manusia. Kencana Prenada Media Group. Medan.

Yuliantini Tine, The Effect of Leadership, Supervision and Imposition of Sanctions (Punishment) Against Employee Work Discipline of PT. Charisma Blessing Initiative, Journal of Economics and Sustainable Development www.iiste.org ISSN 2222-1700 (Paper) ISSN 2222-2855 (Online) Vol.10, No.20, 2019

Wibowo. 2015. Manajemen Kinerja. Edisi Kelima. PT. Rajagrafindo Persada. Medan.

Wilson, B. 2012. Manajemen sumber daya manusia. Erlangga. Bandung 